\title{
MAPK inhibitors augment gallic acid-induced A549 lung cancer cell death through the enhancement of glutathione depletion
}

\author{
WOO HYUN PARK and SUHN HEE KIM
}

\begin{abstract}
Department of Physiology, Medical School, Research Institute for Endocrine Sciences, Chonbuk National University, Jeonju 561-180, Republic of Korea
\end{abstract}

Received February 7, 2013; Accepted April 12, 2013

DOI: $10.3892 /$ or.2013.2447

\begin{abstract}
Gallic acid (GA) is involved in various biological processes such as cell growth inhibition and apoptosis through changes in reactive oxygen species (ROS). In the present study, we investigated the effects of MAPK (MEK, JNK or p38) inhibitors on cell death in GA-induced A549 lung cancer cells in relation to ROS and glutathione (GSH). Treatment with $100 \mu \mathrm{M} \mathrm{GA}$ inhibited the growth of A549 cells and induced apoptosis and/or necrosis, which was accompanied by the loss of mitochondrial membrane potential (MMP; $\Delta \Psi_{\mathrm{m}}$ ). GA increased ROS levels as well as GSH depletion in A549 cells at $24 \mathrm{~h}$. MEK inhibitor seemed to enhance cell growth inhibition by GA. This inhibitor also increased cell death, MMP $\left(\Delta \Psi_{\mathrm{m}}\right)$ loss and GSH depletion in GA-treated A549 cells. Both JNK and p38 inhibitors intensified growth inhibition, cell death, MMP $\left(\Delta \Psi_{\mathrm{m}}\right)$ loss and GSH depletion by GA. However, none of the MAPK inhibitors significantly altered ROS levels in GA-treated A549 cells. In conclusion, MAPK inhibitors enhanced growth inhibition and death in GA-treated A549 cells, which were correlated with GSH depletion rather than ROS levels.
\end{abstract}

Correspondence to: Professor Woo Hyun Park, Department of Physiology, Medical School, Research Institute for Endocrine Sciences, Chonbuk National University, Jeonju 561-180, Republic of Korea

E-mail: parkwh71@chonbuk.ac.kr

Abbreviations: GA, gallic acid; ROS, reactive oxygen species; MAPK, mitogen-activated protein kinase; MEK, MAP kinase or ERK kinase; ERK, extracellular signal-regulated kinase; JNK, c-Jun N-terminal kinase; SOD, superoxide dismutase; MMP $\left(\Delta \Psi_{\mathrm{m}}\right)$, mitochondrial membrane potential; FBS, fetal bovine serum; FITC, fluorescein isothiocyanate; $\mathrm{H}_{2}$ DCFDA, 2',7'-dichlorodihydrofluorescein diacetate; DHE, dihydroethidium; GSH, glutathione; CMFDA, 5-chloromethylfluorescein diacetate; PI, propidium iodide; MTT, 3-(4,5-dimethylthiazol-2-yl)-2,5diphenyltetrazolium bromide

Keywords: gallic acid, cell death, A549, mitogen-activated protein kinase, reactive oxygen species, glutathione

\section{Introduction}

Gallic acid (GA; 3,4,5-trihydroxyl-benzoic acid) is a polyhydroxylphenolic compound, which is broadly disseminated in a variety of plants, fruits and foods (1). It is easily absorbed in humans; micromolar concentrations of free and glucuronidated forms of GA and its major metabolite 4-O-methylgallic acid have been detected in human blood plasma following the ingestion of GA-rich food (2). Diverse biological activities of GA have been reported, including anti-bacterial (3), antiviral (4) and anti-inflammatory (5). The main focus among the properties of GA is connected to its antitumoral action. In fact, anticancer activity of GA has been reported in various cancer cells such as leukemia (6), prostate cancer $(7,8)$, lung cancer $(9,10)$, gastric, colon, breast, cervical and esophageal cancer (11). Apoptosis induced by GA is associated with oxidative stresses derived from reactive oxygen species (ROS), mitochondrial dysfunction and an increase in intracellular $\mathrm{Ca}^{2+}$ level $(6,12)$. GA has both pro- and anti-oxidant properties depending on the concentrations of iron or hydrogen peroxide $\left(\mathrm{H}_{2} \mathrm{O}_{2}\right)$ in medium and plasma $(13,14)$.

The major ROS include $\mathrm{H}_{2} \mathrm{O}_{2}$, superoxide anion $\left(\mathrm{O}_{2}{ }^{--}\right)$ and hydroxyl radical $\left({ }^{\circ} \mathrm{OH}\right) \cdot \mathrm{O}_{2}{ }^{-}$is metabolized to $\mathrm{H}_{2} \mathrm{O}_{2}$ by superoxide dismutases (15). $\mathrm{H}_{2} \mathrm{O}_{2}$ is further detoxified to $\mathrm{O}_{2}$ and $\mathrm{H}_{2} \mathrm{O}$ by catalase or glutathione (GSH) (16). They affect the activity of mitogen-activated protein kinases (MAPKs), which are involved in crucial signaling pathways in cell proliferation, differentiation and cell death in response to a variety of stimuli $(17,18)$. MAPKs can sense the cellular redox status and are common targets for ROS. There are currently three well known MAPKs: the extracellular signal regulated kinase (ERK1/2), the c-Jun N-terminal kinase/stress-activated protein kinase (JNK/SAPK) and the p38 (17). Each MAP kinase pathway has comparatively different upstream activators and specific substrates (19). In general, JNK and p38 are activated by ROS or a mild oxidative shift, initiating procedures related to apoptosis $(20,21)$. ROS also induce ERK phosphorylation and activate the ERK pathway (22). In most cases, ERK signaling has pro-survival and proliferative roles rather than pro-apoptotic effects (23).

Lung cancer is a major cause of cancer-related mortality in developed countries. The carcinogenesis of lung cancer is associated with excessive inflammation mediated by ROS of airborne and bloodborne origin. Various novel remedial 
strategies are still under consideration since the clinical use of conventional drugs is limited due to intrinsic or acquired resistance and toxicity (24). We recently reported that GA inhibits the growth of Calu-6 and A549 lung cancer cells $(25,26)$. In addition, MEK inhibitor PD98059 attenuates growth inhibition and death in GA-treated Calu- 6 cells (27). Since different and opposite effects of MAPKs by a variety of ROS can occur even in the same type of cells, the relationship between ROS and MAPKs requires further elucidation regarding signalings related to cell survival and cell death. In the present study, we investigated the effects of MAPK inhibitors on cell growth, death, ROS and GSH levels in GA-treated A549 lung cancer cells.

\section{Materials and methods}

Cell culture. The human pulmonary adenocarcinoma A549 cell line was obtained from the American Type Culture Collection (ATCC, Manassas, VA, USA) and maintained in a humidified incubator containing $5 \% \mathrm{CO}_{2}$ at $37^{\circ} \mathrm{C}$. A549 cells were cultured in RPMI-1640 supplemented with $10 \%$ fetal bovine serum (FBS) and $1 \%$ penicillin-streptomycin (GibcoBRL, Grand Island, NY, USA).

Reagents. GA was purchased from Sigma-Aldrich Chemical Co. (St. Louis, MO, USA) and was dissolved in ethanol at $200 \mathrm{mM}$ as a stock solution. MEK inhibitor (PD98059), JNK inhibitor (SP600125) and p38 inhibitor (SB203580) were obtained from Calbiochem (San Diego, CA, USA) and were dissolved in DMSO at $10 \mathrm{mM}$ as a stock solution. Cells were pretreated with each MAPK inhibitor for 30 min prior to GA treatment. Based on a previous experiment (28), $10 \mu \mathrm{M}$ of each MAPK inhibitor was used as an optimal dose in this experiment. Ethanol (0.2\%) and DMSO $(0.3 \%)$ were used as a control vehicle.

Cell growth assay. The effect of drugs on A549 cell growth was determined by trypan blue exclusion cell counting or measuring 3-(4,5-dimethylthiazol-2-yl)-2,5-diphenyltetrazolium bromide (MTT) dye absorbance of living cells as previously described (29). In brief, $2 \times 10^{5}$ cells/well were seeded in 24-well plates (Nunc, Roskilde, Denmark) for cell counting and $5 \times 10^{4}$ cells/well were seeded in 96-well microtiter plates for an MTT assay. Following exposure to the indicated dose of GA and/or each MAPK inhibitor for $24 \mathrm{~h}, 20 \mu \mathrm{l}$ of MTT (Sigma) solution ( $2 \mathrm{mg} / \mathrm{ml}$ in PBS) were added to each well of 96-well plates. The plates were incubated for an additional $4 \mathrm{~h}$ at $37^{\circ} \mathrm{C}$. Medium in plates was withdrawn using pipetting and $200 \mu \mathrm{l}$ DMSO was added to each well to solubilize the formazan crystals. Optical density was measured at $570 \mathrm{~nm}$ using a microplate reader (Spectra MAX 340, Molecular Devices Co., Sunnyvale, CA, USA).

Sub-G1 DNA content analysis. Sub-G1 DNA content cells were determined by propidium iodide (PI; Ex/Em=488 nm/617 nm, Sigma-Aldrich) staining as previously described (30). In brief, $1 \times 10^{6}$ cells in $60-\mathrm{mm}$ culture dishes (Nunc) were incubated with GA and/or each MAPK inhibitor for $24 \mathrm{~h}$. Cells were then washed with PBS and fixed in 70\% ethanol. Cells were washed again with PBS, then incubated with PI $(10 \mu \mathrm{g} / \mathrm{ml})$ with simultaneous RNase treatment at $37^{\circ} \mathrm{C}$ for $30 \mathrm{~min}$. Cell
A

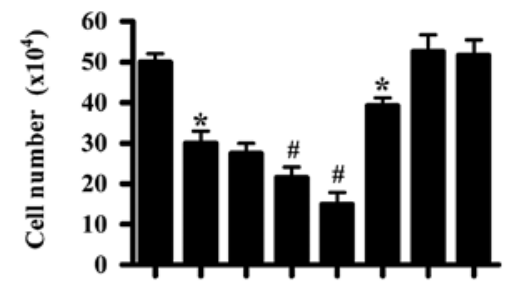

B

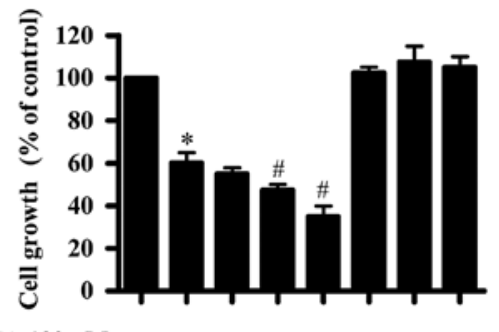

Figure 1. Effects of MAPK inhibitors on cell growth in GA-treated A549 cells. Exponentially growing cells were treated with $100 \mu \mathrm{M} \mathrm{GA}$ for $24 \mathrm{~h}$ following a 30-min pre-incubation of $10 \mu \mathrm{M}$ MEK, JNK or p38 inhibitor. (A) Cell number and (B) cell growth were assessed by trypan blue exclusion cell counting and MTT assays, respectively. ${ }^{*} \mathrm{P}<0.05$ compared with the control group. ${ }^{\#} \mathrm{P}<0.05$ compared with cells treated with GA only.

DNA content was measured using a FACStar flow cytometer (Becton Dickinson, San Jose, CA, USA).

Annexin V staining for cell death detection. Apoptosis was determined by staining cells with Annexin V-fluorescein isothiocyanate (FITC; $\mathrm{Ex} / \mathrm{Em}=488 \mathrm{~nm} / 519 \mathrm{~nm}$, Invitrogen Corp., Camarillo, CA, USA) as previously described $(30,31)$. In brief, $1 \times 10^{6}$ cells in $60-\mathrm{mm}$ culture dishes (Nunc) were incubated with GA and/or each MAPK inhibitor for $24 \mathrm{~h}$. Cells were washed twice with cold PBS and then resuspended in $500 \mu \mathrm{l}$ of binding buffer $(10 \mathrm{mM}$ HEPES/NaOH $\mathrm{pH} \mathrm{7.4,140 \textrm {mM } \mathrm { NaCl } , 2 . 5 \mathrm { mM } \mathrm { CaCl }}$ ) at a concentration of $1 \times 10^{6}$ cells $/ \mathrm{ml}$. Annexin V-FITC $(5 \mu \mathrm{l})$ was then added to these cells, which were analyzed with a FACStar flow cytometer (Becton-Dickinson).

Measurement of mitochondrial membrane potential (MMP; $\left.\Delta \Psi_{m}\right)$. MMP $\left(\Delta \Psi_{\mathrm{m}}\right)$ levels were measured by a rhodamine 123 fluorescent dye $(E x / E m=485 \mathrm{~nm} / 535 \mathrm{~nm}$, Sigma-Aldrich Chemical Co.) as previously described $(31,32)$. In brief, $1 \times 10^{6}$ cells in $60-\mathrm{mm}$ culture dishes (Nunc) were incubated with GA and/or each MAPK inhibitor for $24 \mathrm{~h}$. Cells were washed twice with PBS and incubated with the rhodamine 123 $(0.1 \mu \mathrm{g} / \mathrm{ml})$ at $37^{\circ} \mathrm{C}$ for $30 \mathrm{~min}$. Rhodamine 123 staining intensity was determined by flow cytometry. Rhodamine 123 negative cells indicated the loss of MMP $\left(\Delta \Psi_{\mathrm{m}}\right)$ in A549 cells. $\operatorname{MMP}\left(\Delta \Psi_{\mathrm{m}}\right)$ levels in cells except MMP $\left(\Delta \Psi_{\mathrm{m}}\right)$ loss cells were expressed as mean fluorescence intensity (MFI), which was calculated by CellQuest software.

Detection of intracellular ROS levels. Intracellular ROS such as $\mathrm{H}_{2} \mathrm{O}_{2}$, $\mathrm{OH}$ and $\mathrm{ONOO}^{*}$ were detected by means of an oxidationsensitive fluorescent probe dye, 2',7'-dichlorodihydrofluorescein diacetate $\left(\mathrm{H}_{2} \mathrm{DCFDA}\right.$; Ex/Em=495 nm/529 nm, Invitrogen 
A
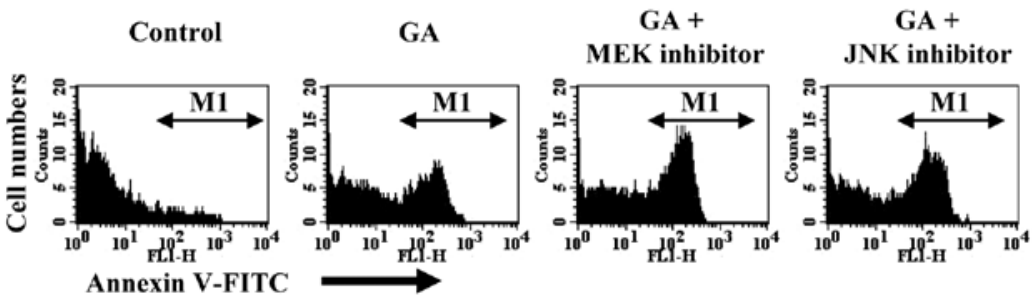

GA +
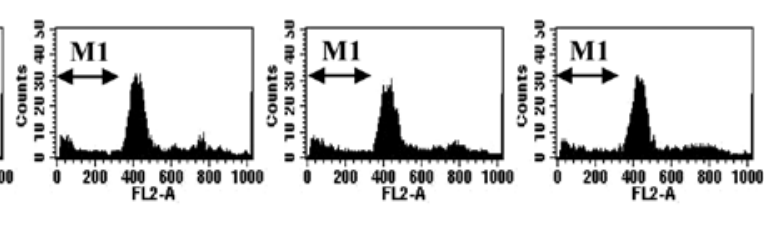

C

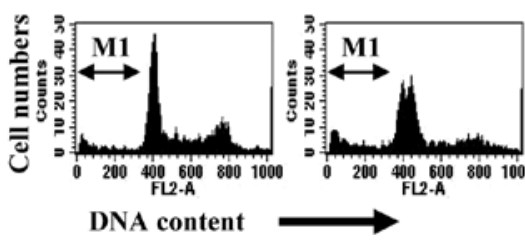

仓̊

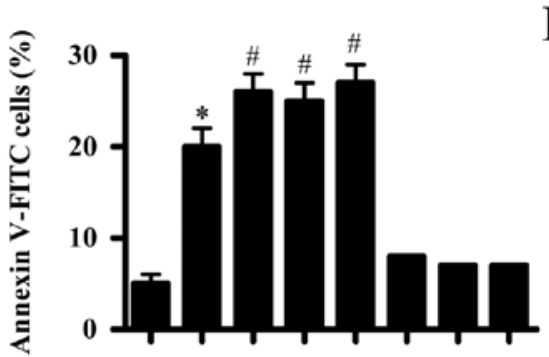

GA $100 \mu \mathrm{M}:-++++-\quad-$

MEK inhibitor $10 \mu \mathrm{M}$ : - $-+\quad-\quad+-$

JNK inhibitor $10 \mu \mathrm{M}:-\quad-\quad+--+$

p38 inhibitor $10 \mu \mathrm{M}$ : - $-\quad-\quad+-\quad-+$
D

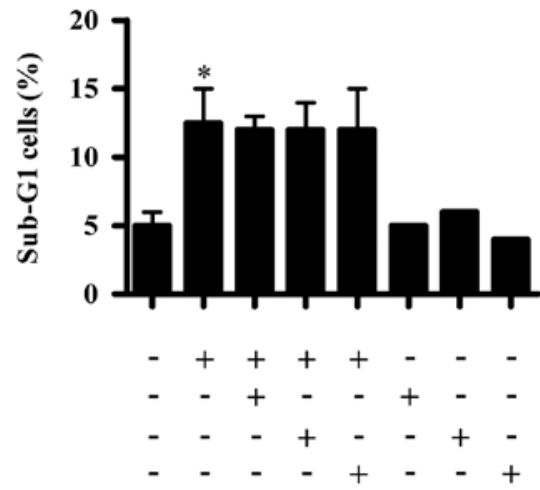

Figure 2. Effects of MAPK inhibitors on cell death in GA-treated A549 cells. Exponentially growing cells were treated with $100 \mu$ M GA for 24 h following a 30-min pre-incubation of $10 \mu \mathrm{M}$ MEK, JNK or p38 inhibitor. Annexin V-FITC and sub-G1 cells were measured with a FACStar flow cytometer. (A and B) Each histogram as a representative indicates Annexin V and sub-G1 cells, respectively. M1 in A indicates Annexin V staining cells. M1 in B indicates sub-G1 cells. (C and D) Graphs show the percentage of Annexin V positive staining cells (M1 region in A) (C) and sub-G1 cells (M1 region in B) (D). * $<<0.05$ compared with the control group. ${ }^{\text {P }}<0.05$ compared with cells treated with GA only.

Molecular Probes, Eugene, OR, USA) (33). $\mathrm{H}_{2}$ DCFDA is poorly selective for $\mathrm{O}_{2}^{-}$. By contrast, dihydroethidium (DHE; Ex/ $\mathrm{Em}=518 \mathrm{~nm} / 605 \mathrm{~nm}$, Invitrogen Molecular Probes) is highly selective for $\mathrm{O}_{2}{ }^{-}$among ROS. In brief, $1 \times 10^{6}$ cells in $60-\mathrm{mm}$ culture dishes (Nunc) were incubated with GA and/or each MAPK inhibitor for $24 \mathrm{~h}$. Cells were then washed in PBS and incubated with $20 \mu \mathrm{M} \mathrm{H}_{2} \mathrm{DCFDA}$ or DHE at $37^{\circ} \mathrm{C}$ for $30 \mathrm{~min}$. DCF and DHE fluorescences were detected using a FACStar flow cytometer (Becton-Dickinson). $\mathrm{ROS}$ and $\mathrm{O}_{2}^{\circ-}$ levels were expressed as MFI, which was calculated by CellQuest software.

Detection of the intracellular GSH. Cellular GSH levels were analyzed using a 5-chloromethylfluorescein diacetate dye (CMFDA, Ex/Em=522 nm/595 nm; Invitrogen Molecular Probes) as previously described $(34,35)$. In brief, $1 \times 10^{6}$ cells in 60-mm culture dishes (Nunc) were incubated with GA and/ or each MAPK inhibitor for $24 \mathrm{~h}$. Cells were then washed with PBS and incubated with $5 \mu \mathrm{M} \mathrm{CMFDA} \mathrm{at} 37^{\circ} \mathrm{C}$ for $30 \mathrm{~min}$. CMF fluorescence intensity was determined using a FACStar flow cytometer (Becton-Dickinson). Negative CMF staining (GSH-depleted) cells were expressed as the percentage of (-) CMF cells. CMF levels in cells except GSH-depleted cells were expressed as MFI, which was calculated by CellQuest software.

Statistical analysis. The results represent at least three independent experiments (means \pm SD). The data were analyzed using Instat software (GraphPad Prism 4, San Diego, CA, USA). One-way analysis of variance (ANOVA) with post hoc analysis using Tukey's multiple comparison test was used for parametric data. $\mathrm{P}<0.05$ was considered to indicate a statistically significant difference.

\section{Results}

Effects of MAPK inhibitors on cell growth in GA-treated A549 cells. We examined the effects of MAPK inhibitors on the growth of GA-treated A549 cells. GA dose-dependently inhibited A549 cell growth with an $\mathrm{IC}_{50}$ of $\sim 150 \mu \mathrm{M}$ at $24 \mathrm{~h}$ (25). Treatment with $100 \mu \mathrm{M}$ GA used in this study inhibited the growth of A549 cells $\sim 40 \%$ based on trypan blue cell counting and MTT assays at $24 \mathrm{~h}$ (Fig. 1A and B). It has been demonstrated that high dose usages of MAPK inhibitors may decrease their specificity (36). In fact, $20 \mu \mathrm{M}$ concentration of each MAPK inhibitor significantly induced cell growth inhibition and death in A549 cells (data not shown). Therefore, the concentration of $10 \mu \mathrm{M}$ each MAPK inhibitor was used in the current experiments to evade the non-specific inhibition of other kinases. While MEK inhibitor slightly enhanced the growth inhibition by GA, JNK and p38 inhibitors significantly enhanced the growth inhibition (Fig. 1A and B). Only MEK inhibitor decreased cell number in A549 control cells (Fig. 1A). The $10 \mu \mathrm{M}$ MAPK inhibitors did not affect A549 control cell growth (Fig. 1B). 
A

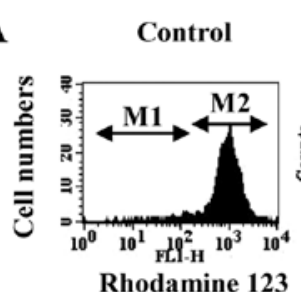

B

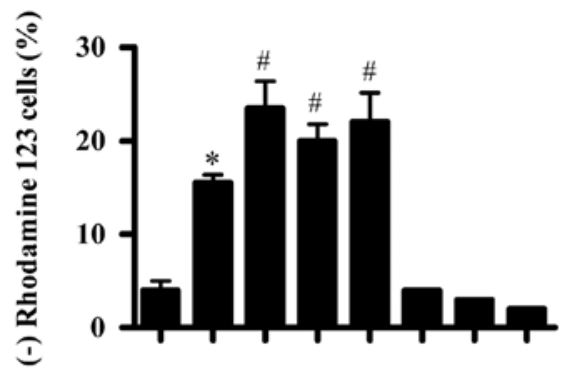

GA $100 \mu \mathrm{M}:-++++-\quad-$

MEK inhibitor $10 \mu \mathrm{M}:-\quad-+-\quad+-$

JNK inhibitor $10 \mu \mathrm{M}:-\quad-\quad+\quad-\quad+\quad-$

p38 inhibitor $10 \mu \mathrm{M}:-\quad-\quad-\quad+-\quad-\quad+$
$\mathrm{GA}+$ MEK inhibitor

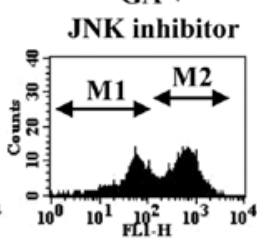

$\mathbf{G A}+$

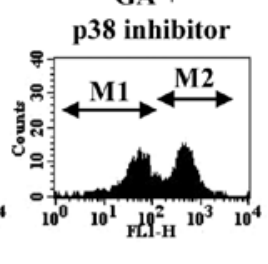

C

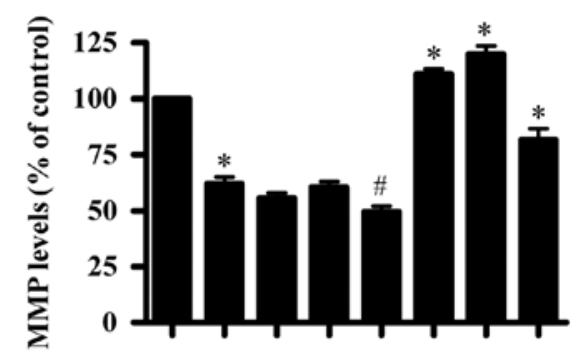

$-++++-\quad-$

$-++-\infty+-$

$-\quad-+-\quad+-$

Figure 3. Effects of MAPK inhibitors on MMP $\left(\Delta \Psi_{\mathrm{m}}\right)$ in GA-treated A549 cells. Exponentially growing cells were treated with $100 \mu \mathrm{M}$ GA for 24 h following a 30-min pre-incubation of $10 \mu \mathrm{M}$ MEK, JNK or p38 inhibitor. MMP $\left(\Delta \Psi_{\mathrm{m}}\right.$ ) in A549 cells was measured with a FACStar flow cytometer. (A) Each histogram as a representative indicates MMP $\left(\Delta \Psi_{\mathrm{m}}\right)$. M1 regions indicate rhodamine 123 negative $\left[\mathrm{MMP}\left(\Delta \Psi_{\mathrm{m}}\right)\right.$ loss] cells. M2 regions indicate cells except rhodamine 123 negative [MMP $\left(\Delta \Psi_{\mathrm{m}}\right)$ loss] cells. (B and C) Graphs show the percentage of rhodamine 123 negative [MMP ( $\left.\Delta \Psi_{\mathrm{m}}\right)$ loss] cells from M1 regions of A (B) and $\operatorname{MMP}\left(\Delta \Psi_{\mathrm{m}}\right)$ levels $(\%)$ from M2 regions of $\mathrm{A}(\mathrm{C}) .{ }^{*} \mathrm{P}<0.05$ compared with the control group. "P $<0.05$ compared with cells treated with $\mathrm{GA}$ only.

A

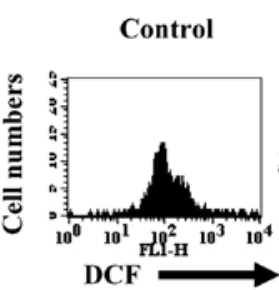

B

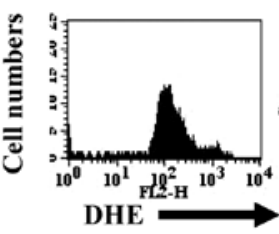

C

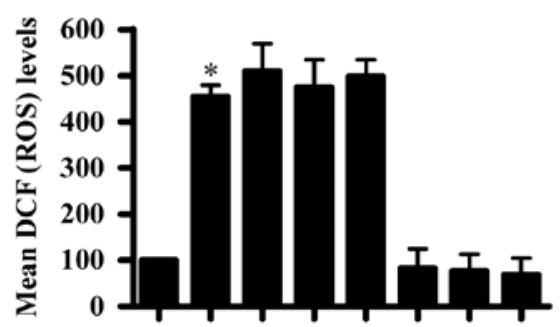

GA $100 \mu \mathrm{M}:-++++-\quad+-$

MEK inhibitor $10 \mu \mathrm{M}:-\quad+\quad-\quad+-$

JNK inhibitor $10 \mu \mathrm{M}:-\quad-\quad+\quad-\quad-+$

p38 inhibitor $10 \mu \mathrm{M}$ : - $-\quad-\quad+\quad-\quad+$
$\mathbf{G A}+$

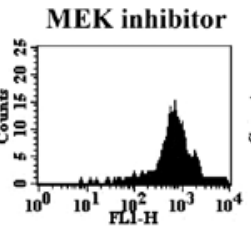

$\mathbf{G A}+$
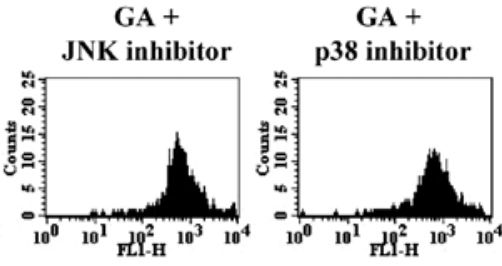
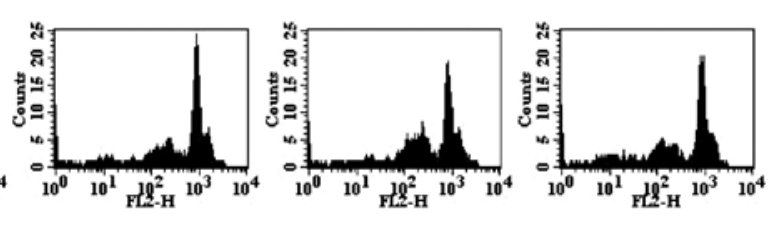

D

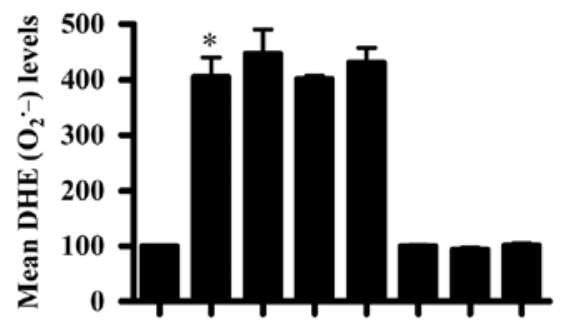

Figure 4. Effects of MAPK inhibitors on ROS levels in GA-treated A549 cells. Exponentially growing cells were treated with $100 \mu$ M GA for 24 h following a 30-min pre-incubation of $10 \mu \mathrm{M}$ MEK, JNK or p38 inhibitor. ROS levels in A549 cells were measured using a FACStar flow cytometer. (A and B) Each histogram as a representative indicates DCF and DHE levels in each cell group, respectively. (C and D) Graphs indicate DCF (ROS) levels (\%) compared with GA-untreated control cells (C) and DHE $\left(\mathrm{O}_{2}{ }^{-}\right)$levels $(\%)$ compared with GA-untreated control cells (D). ${ }^{*} \mathrm{P}<0.05$ compared with the control group. ${ }^{\#} \mathrm{P}<0.05$ compared with cells treated with GA only. 


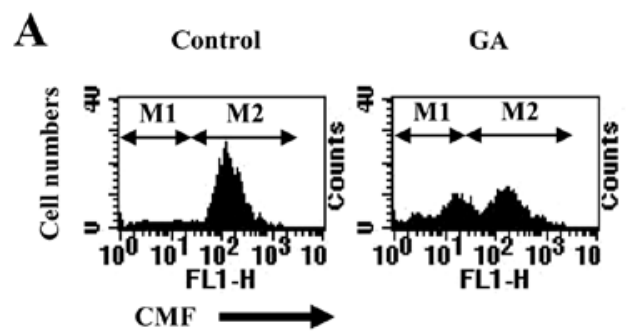

B

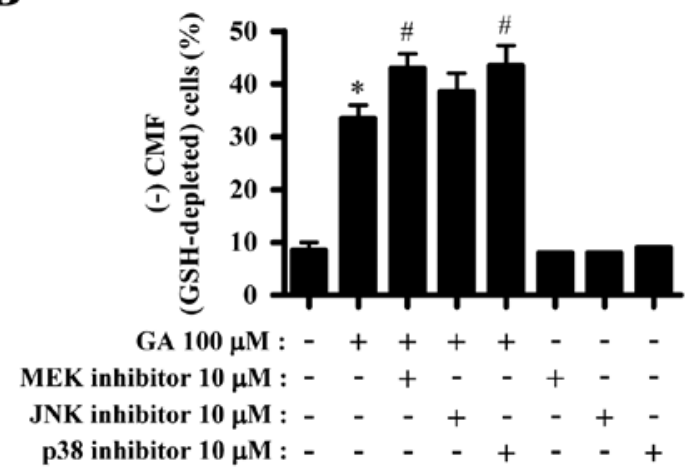

GA + MEK inhibitor

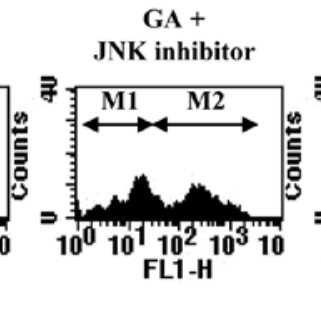

GA +

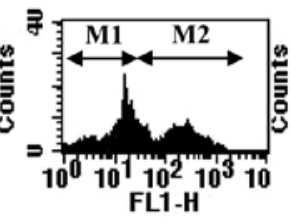

C

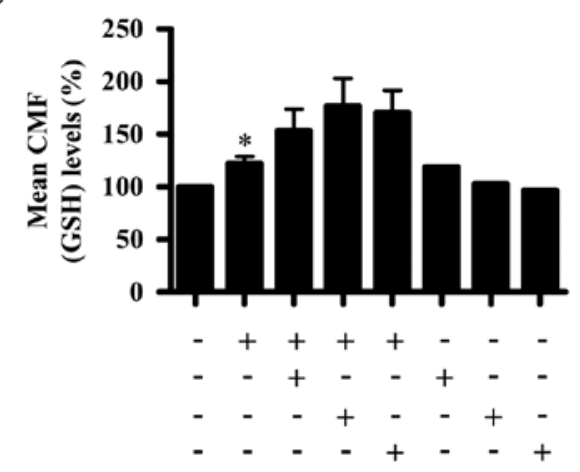

Figure 5. Effects of MAPK inhibitors on GSH levels in GA-treated A549 cells. Exponentially growing cells were treated with $100 \mu \mathrm{M} \mathrm{GA}$ for $24 \mathrm{~h}$ following a 30-min pre-incubation of $10 \mu \mathrm{M}$ MEK, JNK or p38 inhibitor. GSH levels in A549 cells were measured using a FACStar flow cytometer. (A) Each histogram as a representative shows CMF intensities in cells. M1 indicates (-) CMF (GSH-depleted) cells. M2 indicates cells except (-) CMF cells. (B and C) Graphs show the percentage of (-) CMF (GSH-depleted) cells (M1 region in A) (B) and mean CMF (GSH) levels compared with GA-untreated control cells (M2 region in A) (C). ${ }^{*} \mathrm{P}<0.05$ compared with the control group. ${ }^{\#} \mathrm{P}<0.05$ compared with cells treated with GA only.

Effects of MAPK inhibitors on cell death and MMP $\left(\Delta \Psi_{m}\right)$ in GA-treated A549 cells. GA significantly induced cell death in A549 cells, as evidenced by trypan blue positive staining (Fig. 1A) and Annexin V staining cells (Fig. 2A and C). However, GA slightly increased the number of sub-G1 DNA content cells (Fig. 2B and D). All the MAPK inhibitors increased the number of Annexin V staining cells in GA-treated A549 cells (Fig. 2A and C). However, none of the MAPK inhibitors altered the number of sub-G1 cells (Fig. 2B and D) and none of the MAPK inhibitors affected the number of Annexin V staining and sub-G1 cells in A549 control cells (Fig. 2C and D).

In addition, GA significantly triggered the loss of MMP $\left(\Delta \Psi_{\mathrm{m}}\right)$ in A549 cells (Fig. 3A and B). All the MAPK inhibitors intensified the MMP $\left(\Delta \Psi_{\mathrm{m}}\right)$ loss in GA-treated A549 cells (Fig. 3A and B). In relation to MMP $\left(\Delta \Psi_{\mathrm{m}}\right)$ levels, GA reduced MMP $\left(\Delta \Psi_{\mathrm{m}}\right)$ levels in A549 cells (Fig. 3A and C). Only p38 inhibitor significantly decreased MMP $\left(\Delta \Psi_{\mathrm{m}}\right)$ levels in GA-treated A549 cells (Fig. 3A and C). Although MEK or JNK inhibitor alone increased $\operatorname{MMP}\left(\Delta \Psi_{\mathrm{m}}\right)$ levels in A549 control cells, p38 inhibitor reduced the MMP $\left(\Delta \Psi_{\mathrm{m}}\right)$ levels (Fig. 3A and C).

Effects of MAPK inhibitors on ROS and GSH levels in GA-treated A549 cells. Next, we determined whether intracellular ROS and GSH levels in GA-treated A549 cells were altered by treatment with each MAPK inhibitor. ROS (DCF) level such as $\mathrm{H}_{2} \mathrm{O}_{2}$ was increased in GA-treated A549 cells (Fig. 4A and C). The MAPK inhibitors did not significantly change ROS level in GA-treated A549 cells (Fig. 4A and C). Red fluorescence derived from DHE reflecting intracellular $\mathrm{O}_{2}{ }^{-}$level was also increased in A549 cells (Fig. 4B and D). None of the MAPK inhibitors altered $\mathrm{O}_{2}{ }^{--}$levels in GA-treated
A549 cells (Fig. 4B and D). The MAPK inhibitors did not alter ROS level in A549 control cells (Fig. 4C and D).

GA increased the number of GSH-depleted cells in A549 cells (Fig. 5A and B). MEK and p38 inhibitors significantly increased GSH-depleted cell number in GA-treated A549 cells and JNK inhibitor showed a light effect on that (Fig. 5A and B). In addition, GA increased GSH level in A549 cells (Fig. 5A and C). All the MAPK inhibitors seemed to intensify the increased GSH level by GA (Fig. 5A and C).

\section{Discussion}

Since GA inhibited the growth of A549 cells and induced their death, we focused on elucidating the toxicological effect of GA on cell growth and death in A549 cells pretreated with MAPK inhibitors in relation to ROS and GSH. GA increased Annexin V-FITC positive cells in A549 cells, which indirectly indicated that GA-induced A549 cell death occurred via apoptosis. However, GA did not increase sub-G1 cell number as much as Annexin $\mathrm{V}$ positive cell number by it. In addition, $200 \mu \mathrm{M}$ GA did not increase sub-G1 cell number compared with the number in $100 \mu \mathrm{M}$ GA-treated cells (data not shown). Therefore, GA seemed to induce growth inhibition in A549 cells via necrosis as well as apoptosis.

ERK activation has a pro-survival function rather than pro-apoptotic effects (23). Similarly, MEK inhibitor, which presumably decreased ERK activity, slightly enhanced the growth inhibition by GA and significantly intensified cell death by it. In addition, MEK inhibitor alone significantly reduced the number of A549 control cells. Therefore, this result indirectly suggested that the inhibition of ERK signaling by MEK inhibitor plays a pro-apoptotic role in GA-treated A549 cells and has 
an anti-growth function in A549 control cells. However, MEK inhibitor attenuates growth inhibition and death in GA-treated Calu- 6 cells (27), indicating that MEK inhibitor differently affects cell growth and death in GA-treated A549 and Calu-6 lung cancer cells. Moreover, MEK inhibitor did not affect cell growth inhibition and death in GA-treated human pulmonary fibroblast cells (37). Therefore, the targeted therapy related to ERK signaling should be carefully considered in lung cancer treatment. Considerable evidence demonstrates that JNK or p38 signaling is related to cell death $(20,21)$. In fact, GA induces PC12 rat pheochromocytoma cell death through the activation of $\mathrm{JNK}$ and its inhibitor protects $\mathrm{PC} 12$ cells against GA-induced cell death (38). In addition, p38 inhibitor prevented anisomycin-induced macrophage death (39) and its inhibitor decreased the death of pyrogallol-induced calf pulmonary artery endothelial cells (28). Moreover, JNK and p38 inhibitors do not significantly alter cell death in GA-treated human pulmonary fibroblast cells and Calu- 6 cells $(27,37)$. However, results of the present study demonstrated that JNK or p38 inhibitor enhanced growth inhibition and death in GA-treated A549 cells. It is also demonstrated that JNK and p38 inhibitors enhance cell growth inhibition and death in GA-treated HeLa cells (40). Therefore, the inhibition of JNK or p38 signaling by each inhibitor seemed to be a pro-apoptotic function in GA-treated A549 cells. Collectively, anti- or pro-apoptotic effects of JNK or p38 inhibitor depend on cell types or co-treated agents. Markedly, none of the MAPK inhibitors increased the number of sub-G1 cells in GA-treated A549 cells. These results indicated that the inhibition of each MAPK signaling by its inhibitor was involved in the enhancement of apoptosis rather than necrosis.

Cell death induced by GA is associated with mitochondrial dysfunction (12). Accordingly, GA induced the loss of MMP $\left(\Delta \Psi_{\mathrm{m}}\right)$ in A549 cells and reduced MMP $\left(\Delta \Psi_{\mathrm{m}}\right)$ levels. All the MAPK inhibitors intensified MMP $\left(\Delta \Psi_{\mathrm{m}}\right)$ loss in GA-treated A549 cells. Therefore, the cell death by GA and/or MAPK inhibitors seemed to be tightly connected with the loss of MMP $\left(\Delta \Psi_{\mathrm{m}}\right)$. In addition, p38 inhibitor significantly reduced MMP $\left(\Delta \Psi_{\mathrm{m}}\right)$ levels in GA-treated A549 cells. This result likely clarifies the strong growth inhibition of A549 cells by co-treatment with GA and p38 inhibitor since MTT reduction is considered to be an indirect measurement of mitochondrial activity (41). However, since all the MAPK inhibitors affected the basal MMP $\left(\Delta \Psi_{\mathrm{m}}\right)$ level in A549 control cells without changes in cell growth, the changes in MMP $\left(\Delta \Psi_{\mathrm{m}}\right)$ levels are not fully associated with those of MTT reduction in cells. Nevertheless, the basal activity of MAPK signalings seemed to be involved in the maintenance of MMP $\left(\Delta \Psi_{\mathrm{m}}\right)$ in A549 control cells.

Increasing evidence suggests that apoptosis induced by GA is associated with oxidative stresses derived from ROS $(6,42)$. Similarly, ROS levels including $\mathrm{O}_{2}^{--}$were significantly increased in GA-treated A549 cells. The MAPK inhibitors did not significantly alter ROS levels in GA-treated A549 cells. These data suggest that changes in ROS levels by MAPK inhibitors in GA-treated A549 cells are not closely related to cell death. GSH is a main non-protein antioxidant and eliminates the $\mathrm{O}_{2}^{--}$by providing electrons for enzymes such as GSH peroxidase, which reduce $\mathrm{H}_{2} \mathrm{O}_{2}$ to $\mathrm{H}_{2} \mathrm{O}$. It has been reported that the intracellular GSH content has a decisive effect on anticancer drug-induced apoptosis, indicating that apoptotic effects are inversely comparative to GSH content $(34,43,44)$. Similarly, GA increased the number of GSH-depleted cells in A549 cells. MEK and p38 inhibitors significantly enhanced GSH depletion in GA-treated A549 cells, and JNK inhibitor slightly increased the number. These results might be correlated with the results derived from Annexin $\mathrm{V}$ and $\operatorname{MMP}\left(\Delta \Psi_{\mathrm{m}}\right)$ assays. These results support the hypothesis that the intracellular GSH content has a decisive effect on cell death $(32,34,45,46)$. It is of note that CMF (GSH) level in A549 cells was increased by GA. The increased GSH level was likely to occur against the increasing ROS level by GA. It may be that some cells which could not defend oxidative stress resulting from GA treatment underwent cell death pathway. All the MAPK inhibitors enhanced GSH level in GA-treated A549 cells. These results suggest that MAPK inhibitors are involved in the upregulation of GSH levels in GA-treated A549 cells, consequently affecting ROS levels and the proportions of GSH-depleted cells. The mechanism underlying the effect of MAPKs on intracellular GSH level in cells requires further clarification.

In conclusion, GA induced growth inhibition and death in A549 cells, which was accompanied by intracellular ROS increase and GSH depletion. All the MAPK inhibitors enhanced growth inhibition and death in GA-treated A549 cells, which were related to GSH depletion rather than ROS level.

\section{Acknowledgements}

The present study was supported by a grant from the Ministry of Science and Technology (MoST)/Korea Science and Engineering Foundation (KOSEF) through the Diabetes Research Center at Chonbuk National University (20120009323) and the National Research Foundation of Korea Grant funded by the Korean Government (MEST) (2010-0021808).

\section{References}

1. Niemetz R and Gross GG: Enzymology of gallotannin and ellagitannin biosynthesis. Phytochemistry 66: 2001-2011, 2005.

2. Shahrzad S, Aoyagi K, Winter A, Koyama A and Bitsch I: Pharmacokinetics of gallic acid and its relative bioavailability from tea in healthy humans. J Nutr 131: 1207-1210, 2001.

3. Kang MS, Oh JS, Kang IC, Hong SJ and Choi CH: Inhibitory effect of methyl gallate and gallic acid on oral bacteria. J Microbiol 46: 744-750, 2008.

4. Kratz JM, Andrighetti-Frohner CR, Leal PC, Nunes RJ, Yunes RA, Trybala E, Bergstrom T, Barardi CR and Simoes CM: Evaluation of anti-HSV-2 activity of gallic acid and pentyl gallate. Biol Pharm Bull 31: 903-907, 2008.

5. Kim SH, Jun CD, Suk K, Choi BJ, Lim H, Park S, Lee SH, Shin HY, Kim DK and Shin TY: Gallic acid inhibits histamine release and pro-inflammatory cytokine production in mast cells. Toxicol Sci 91: 123-131, 2006.

6. Inoue M, Sakaguchi N, Isuzugawa $\mathrm{K}$, Tani $\mathrm{H}$ and Ogihara $\mathrm{Y}$ : Role of reactive oxygen species in gallic acid-induced apoptosis. Biol Pharm Bull 23: 1153-1157, 2000.

7. Kaur M, Velmurugan B, Rajamanickam S, Agarwal R and Agarwal C: Gallic acid, an active constituent of grape seed extract, exhibits anti-proliferative, pro-apoptotic and antitumorigenic effects against prostate carcinoma xenograft growth in nude mice. Pharm Res 26: 2133-2140, 2009.

8. Veluri R, Singh RP, Liu Z, Thompson JA, Agarwal R and Agarwal C: Fractionation of grape seed extract and identification of gallic acid as one of the major active constituents causing growth inhibition and apoptotic death of DU145 human prostate carcinoma cells. Carcinogenesis 27: 1445-1453, 2006. 
9. Kawada M, Ohno Y, Ri Y, Ikoma T, Yuugetu H, Asai T, Watanabe M, Yasuda N, Akao S, Takemura G, et al: Anti-tumor effect of gallic acid on LL-2 lung cancer cells transplanted in mice. Anticancer Drugs 12: 847-852, 2001.

10. Ohno Y, Fukuda K, Takemura G, Toyota M, Watanabe M, Yasuda N, Xinbin Q, Maruyama R, Akao S, Gotou K, Fujiwara T and Fujiwara $\mathrm{H}$ : Induction of apoptosis by gallic acid in lung cancer cells. Anticancer Drugs 10: 845-851, 1999.

11. Faried A, Kurnia D, Faried LS, Usman N, Miyazaki T, Kato H and Kuwano $\mathrm{H}$ : Anticancer effects of gallic acid isolated from Indonesian herbal medicine, Phaleria macrocarpa (Scheff.) Boerl, on human cancer cell lines. Int J Oncol 30: 605-613, 2007.

12. Chen HM, Wu YC, Chia YC, Chang FR, Hsu HK, Hsieh YC, Chen CC and Yuan SS: Gallic acid, a major component of Toona sinensis leaf extracts, contains a ROS-mediated anti-cancer activity in human prostate cancer cells. Cancer Lett 286: 161-171, 2009.

13. Strlic M, Radovic T, Kolar J and Pihlar B: Anti- and prooxidative properties of gallic acid in fenton-type systems. J Agric Food Chem 50: 6313-6317, 2002.

14. Sakagami $\mathrm{H}$ and Satoh K: Prooxidant action of two antioxidants: ascorbic acid and gallic acid. Anticancer Res 17: 221-224, 1997.

15. Zelko IN, Mariani TJ and Folz RJ: Superoxide dismutase multigene family: a comparison of the CuZn-SOD (SOD1), Mn-SOD (SOD2), and EC-SOD (SOD3) gene structures, evolution, and expression. Free Radic Biol Med 33: 337-349, 2002.

16. Wilcox CS: Reactive oxygen species: roles in blood pressure and kidney function. Curr Hypertens Rep 4: 160-166, 2002.

17. Genestra M: Oxyl radicals, redox-sensitive signalling cascades and antioxidants. Cell Signal 19: 1807-1819, 2007.

18. Blenis J: Signal transduction via the MAP kinases: proceed at your own RSK. Proc Natl Acad Sci USA 90: 5889-5892, 1993.

19. Kusuhara M, Takahashi E, Peterson TE, Abe J, Ishida M, Han J, Ulevitch R and Berk BC: p38 Kinase is a negative regulator of angiotensin II signal transduction in vascular smooth muscle cells: effects on $\mathrm{Na}^{+} / \mathrm{H}^{+}$exchange and ERK1/2. Circ Res 83: 824-831, 1998

20. Hsin YH, Chen CF, Huang S, Shih TS, Lai PS and Chueh PJ: The apoptotic effect of nanosilver is mediated by a ROS- and JNK-dependent mechanism involving the mitochondrial pathway in NIH3T3 cells. Toxicol Lett 179: 130-139, 2008.

21. Mao X, Yu CR, Li WH and Li WX: Induction of apoptosis by shikonin through a ROS/JNK-mediated process in Bcr/Abl-positive chronic myelogenous leukemia (CML) cells. Cell Res 18: 879-888, 2008.

22. Guyton KZ, Liu Y, Gorospe M, Xu Q and Holbrook NJ: Activation of mitogen-activated protein kinase by $\mathrm{H}_{2} \mathrm{O}_{2}$. Role in cell survival following oxidant injury. J Biol Chem 271: 4138-4142, 1996.

23. Henson ES and Gibson SB: Surviving cell death through epidermal growth factor (EGF) signal transduction pathways: implications for cancer therapy. Cell Signal 18: 2089-2097, 2006

24. Petty RD, Nicolson MC, Kerr KM, Collie-Duguid E and Murray GI: Gene expression profiling in non-small cell lung cancer: from molecular mechanisms to clinical application. Clin Cancer Res 10: 3237-3248, 2004.

25. You BR, Kim SZ, Kim SH and Park WH: Gallic acid-induced lung cancer cell death is accompanied by ROS increase and glutathione depletion. Mol Cell Biochem 357: 295-303, 2011.

26. You BR and Park WH: Gallic acid-induced lung cancer cell death is related to glutathione depletion as well as reactive oxygen species increase. Toxicol In Vitro 24: 1356-1362, 2010.

27. Han YH, Moon HJ, You BR, Yang YM, Kim SZ, Kim SH and Park WH: The MEK inhibitor PD98059 attenuates growth inhibition and death in gallic acid-treated Calu-6 lung cancer cells by preventing glutathione depletion. Mol Med Rep 3: 519-524, 2010.

28. Han YH, Moon HJ, You BR, Kim SZ, Kim SH and Park WH: JNK and p38 inhibitors increase and decrease apoptosis, respectively, in pyrogallol-treated calf pulmonary arterial endothelial cells. Int J Mol Med 24: 717-722, 2009.
29. Han YH, Moon HJ, You BR, Kim SZ, Kim SH and Park WH: Effects of carbonyl cyanide p-(trifluoromethoxy) phenylhydrazone on the growth inhibition in human pulmonary adenocarcinoma Calu-6 cells. Toxicology 265: 101-107, 2009.

30. Han YH, Kim SZ, Kim SH and Park WH: Apoptosis in pyrogallol-treated Calu- 6 cells is correlated with the changes of intracellular GSH levels rather than ROS levels. Lung Cancer 59: 301-314, 2008.

31. Han YH, Moon HJ, You BR and Park WH: The effect of MG132, a proteasome inhibitor on HeLa cells in relation to cell growth, reactive oxygen species and GSH. Oncol Rep 22: 215-221, 2009.

32. Han YH, Kim SH, Kim SZ and Park WH: Carbonyl cyanide p-(trifluoromethoxy) phenylhydrazone (FCCP) as an $\mathrm{O}_{2}\left({ }^{*}\right)$ generator induces apoptosis via the depletion of intracellular GSH contents in Calu-6 cells. Lung Cancer 63: 201-209, 2009.

33. Han YH, Kim SH, Kim SZ and Park WH: Caspase inhibitor decreases apoptosis in pyrogallol-treated lung cancer Calu- 6 cells via the prevention of GSH depletion. Int J Oncol 33: 1099-1105, 2008.

34. Han YH, Kim SZ, Kim SH and Park WH: Intracellular GSH level is a factor in As4.1 juxtaglomerular cell death by arsenic trioxide. J Cell Biochem 104: 995-1009, 2008.

35. Han YH and Park WH: Propyl gallate inhibits the growth of HeLa cells via regulating intracellular GSH level. Food Chem Toxicol 47: 2531-2538, 2009.

36. Bain J, McLauchlan H, Elliott M and Cohen P: The specificities of protein kinase inhibitors: an update. Biochem J 371: 199-204, 2003.

37. Park WH: MAPK inhibitors differentially affect gallic acidinduced human pulmonary fibroblast cell growth inhibition. Mol Med Rep 4: 193-204, 2011.

38. Kang MK, Kang NJ, Jang YJ, Lee KW and Lee HJ: Gallic acid induces neuronal cell death through activation of c-Jun $\mathrm{N}$-terminal kinase and downregulation of Bcl-2. Ann NY Acad Sci 1171: 514-520, 2009.

39. Croons V, Martinet W, Herman AG, Timmermans JP and De Meyer GR: The protein synthesis inhibitor anisomycin induces macrophage apoptosis in rabbit atherosclerotic plaques through p38 mitogen-activated protein kinase. J Pharmacol Exp Ther 329: 856-864, 2009.

40. You BR and Park WH: The effects of mitogen-activated protein kinase inhibitors or small interfering RNAs on gallic acidinduced HeLa cell death in relation to reactive oxygen species and glutathione. J Agric Food Chem 59: 763-771, 2011.

41. Marshall NJ, Goodwin CJ and Holt SJ: A critical assessment of the use of microculture tetrazolium assays to measure cell growth and function. Growth Regul 5: 69-84, 1995.

42. Serrano A, Palacios C, Roy G, Cespon C, Villar ML, Nocito M and Gonzalez-Porque P: Derivatives of gallic acid induce apoptosis in tumoral cell lines and inhibit lymphocyte proliferation. Arch Biochem Biophys 350: 49-54, 1998.

43. Han YH, Kim SZ, Kim SH and Park WH: Enhancement of arsenic trioxide-induced apoptosis in HeLa cells by diethyldithiocarbamate or buthionine sulfoximine. Int $\mathrm{J}$ Oncol 33: 205-213, 2008

44. Han YH, Kim SZ, Kim SH and Park WH: Suppression of arsenic trioxide-induced apoptosis in HeLa cells by $\mathrm{N}$-acetylcysteine. Mol Cells 26: 18-25, 2008.

45. Estrela JM, Ortega A and Obrador E: Glutathione in cancer biology and therapy. Crit Rev Clin Lab Sci 43: 143-181, 2006.

46. Han YH, Moon HJ, You BR, Kim SZ, Kim SH and Park WH: The effects of buthionine sulfoximine, diethyldithiocarbamate or 3-amino-1,2,4-triazole on propyl gallate-treated HeLa cells in relation to cell growth, reactive oxygen species and glutathione. Int J Mol Med 24: 261-268, 2009. 